\title{
Bazı Yonca (Medicago sativa L.) Genotiplerinin Kalite Özelliklerinin Belirlenmesi
}

\author{
*Mehmet ÖTEN ${ }^{*}$ Sebahattin ALBAYRAK² \\ ${ }^{1}$ Batı Akdeniz Tarımsal Araștırma Enstitüsü Müdürlüğü, Antalya, Türkiye \\ ${ }^{2}$ Ondokuz Mayıs Üniversitesi, Bafra Meslek Yüksek Okulu, Samsun, Türkiye \\ ${ }^{*}$ Corresponding author e-mail (Sorumlu yazar e-posta): moten07@hotmail.com
}

\begin{abstract}
Öz
Bu çalıșma, 2013-2014 yıllarında Batı Akdeniz Tarımsal Araștırma Enstitüsü deneme alanlarında, tesadüf blokları deneme deseninde üç tekrarlamalı olarak yürütülmüștür. Araștırmadan elde edilen veriler ile ileri kademede olușturulacak yonca ıslah çalsșmalarına materyal temin edilmesi amaçlanmıștır. Bu amaçla Antalya iline ait 13 ilçeden, 26 farkı duraktaki doğal vejetasyondan seçilen üstün yonca genotiplerinde, kalite özelliklerinin belirlenmesi için önem arz eden, ham protein (HP) oranı, asit deterjan fiber (ADF), nötr deterjan fiber (NDF) oranları saptanmıștır. En yüksek HP oranı, Finike1, Finike2, Gazipașa1 ve Aksu2 genotiplerinde, en yüksek ADF oranı, Serik2 genotipinde ve en yüksek NDF oranı ise Manavgat2 genotipinde tespit edilmiștir. Kalite kriterleri açısından Gazipașa1, Alanya1, Aksu2, Kepez1, Döșemealtı1, Konyaaltı1, Kemer1, Finike2, Demre1 ve Kaș1 genotipleri, ileri ıslah kademesine aktarımıștır.
\end{abstract}

Anahtar Kelimeler: Yonca, Kalite, ADF, NDF, HP

\section{Determination of Forage Quality Features of Some Alfalfa (Medicago sativa L.) Genotypes}

\section{Abstract}

This study was carried out in the experimental areas of West Mediterranean Agricultural Research Institute designed in a randomized block trial technique with three replications, throughout 2013-2014. It was aimed to provide material for advanced stage alfalfa breeding studies with the data obtained from the study. For this purpose, 26 superior alfalfa genotypes were selected from the natural vegetation from 13 different districts of Antalya province. The crude protein (CP), acid detergent fiber (ADF) and neutral detergent fiber (NDF) ratios of 26 genotypes were determined to reveal quality specifications. The highest CP values were determined from Finike1, Finike2, Gazipașa1 and Aksu2 genotypes. The highest ADF and NDF ratios were recorded at Serik2 and Manavgat2 genotypes, respectively. Regarding the quality characteristics; Gazipasa1, Alanya1, Aksu2, Kepez1, Dosemealti1, Konyaalti1, Kemer1, Finike2, Demre1 and Kas1genotypes were chosen for the advanced breeding stage.

Keywords: Alfalfa, Quality, CP, ADF, NDF

\section{Giriș}

Türkiye, coğrafi ve iklim özellikleri açısından çok elverișli ve farklı ekolojik bölgelere sahip olup, kültüre alınmıș pek çok bitki türünün gen kaynağı konumundadır (Karagül, 2017). Ancak, bu potansiyeli yeterince değerlendirememektedir. Ülkemiz yoncanın bașlıca gen merkezlerindendir ve hemen hemen her bölgede yabani formları yaygın olarak bulunmaktadır (Gençkan, 1983). Ülkemizde yem bitkileri ekim alanının artırılması ve kaliteli kaba yem ihtiyacının giderilebilmesi için kullanılabilecek bitkilerin en bașında yonca gelmektedir. Yonca (Medicago sativa L.) çok yıllık baklagil yem bitkisidir ve geniș adaptasyon kabiliyeti, toprağa azot bağlaması, birim alandan kaldırdığı protein miktarının fazla olması, mineral madde ve vitaminler bakımından zengin olması gibi özelliklerinden dolayı yem bitkilerinin kraliçesi olarak bilinmektedir (Manga ve ark. 1995). 
Yeni bir çeșit geliștirme așamasında verimle birlikte kalite de büyük önem arz etmektedir. Bütün bitkiler için kullanılmakla birlikte, nispi yem değeri metodu, yonca bitkisinin kalite değerini belirlemek için geliştirilmiş bir metottur (Yavuz, 2005 a). Nispi yem değerinin hesaplanmasında asit deterjan fiber (ADF) ve nötr deterjan fiber (NDF) değerlerinden yararlanılmaktadır. Hayvan beslemede ADF özellikle ruminant rasyonlarında enerji göstergesi olarak (Tekce ve Gül, 2014). NDF ise, bir hayvanın 24 saat içinde ne kadar yem tüketeceğiningöstergesiolarakkullanılmaktadır (Budak ve Budak, 2014). Bașka bir deyișle; ADF değeri, yemin kalitesi hakkında fikir verirken, NDF değeri; yemin hacmi-kabalığı hakkında fikir vermektedir (Kutlu 2008). Nispi yem değerinin hesaplanmasında, öncelikle kaba yemin sindirilebilir kuru madde ve kuru madde tüketimi tespit edilirken, protein içeriği hesaplamaya dahil edilmemektedir (Güney ve ark., 2016). Protein oranı bașlı bașına bir kalite kriteri niteliğindedir. Budak (2014) ham protein oranı \% 12 ve daha düșük ise yem kalitesinin düșük, \%15 ise orta kaliteli, \% 18 ve üzerinde ise yem kalitesinin yüksek olduğunu belirtmiștir.

Bu çalıșma ile yonca genotiplerinde bazı kalite kriterleri baz alınarak, ileri kademelerde olușturulacak yonca ıslah çalıșmalarına materyal temin edilmesi amaçlanmıștır.

\section{Materyal ve Yöntem}

Bu çalıșma, 2013-2014 yıllarında Batı Akdeniz Tarımsal Araștırma Enstitüsü deneme

Çizelge 1. Genotiplerin lokasyonlarına ait rakım ve koordinatlar

Table 1.The altitude and coordinates of locations of the genotypes

\begin{tabular}{|c|c|c|c|}
\hline No & Genotipler & Koordinat & Rakım (m) \\
\hline 1 & Gazipașa1 & 36 S 0435431/UTM4014344 & 5 \\
\hline 2 & Gazipașa2 & 36 S 0435442/UTM4017345 & 5 \\
\hline 3 & Alanya1 & 36 S 0394617/UTM4051485 & 5 \\
\hline 4 & Alanya2 & 36 S 0421487/UTM4035629 & 7 \\
\hline 5 & Manavgat1 & 36 S 0356909/UTM4074395 & 17 \\
\hline 6 & Manavgat2 & 36 S 0370937/UTM4065313 & 15 \\
\hline 7 & Serik1 & 36 S 0336258/UTM4086610 & 20 \\
\hline 8 & Serik2 & 36 S 0319221/UTM4089489 & 15 \\
\hline 9 & Aksu1 & 36 S 0309140/UTM4090629 & 38 \\
\hline 10 & Aksu2 & 36 S 0308518/UTM4093599 & 41 \\
\hline 11 & Kepez1 & 36 S 0291459/UTM4102379 & 94 \\
\hline 12 & Kepez2 & 36 S 0291423/UTM4094089 & 90 \\
\hline 13 & Döșemealtı1 & 36 S 0287925/UTM4115934 & 98 \\
\hline 14 & Döșemealtı2 & 36 S 0287130/UTM4110832 & 95 \\
\hline 15 & Konyaaltı1 & 36 S 0283475/UTM4084515 & 5 \\
\hline 16 & Konyaaltı2 & 36 S 0286970/UTM4081741 & 5 \\
\hline 17 & Kemer1 & 36 S 0277833/UTM4043605 & 5 \\
\hline 18 & Kemer2 & 36 S 0280860/UTM4058454 & 10 \\
\hline 19 & Kumluca1 & 36 S 0254201/UTM4027215 & 6 \\
\hline 20 & Kumluca2 & 36 S 0269439/UTM4024953 & 80 \\
\hline 21 & Finike1 & 36 S 0250386/UTM4026598 & 20 \\
\hline 22 & Finike2 & 36 S 0242661/UTM4023368 & 1 \\
\hline 23 & Demre1 & 36 S 0231189/UTM4014765 & 4 \\
\hline 24 & Demre2 & 36 S 0233864/UTM 4016756 & 2 \\
\hline 25 & Kaș1 & 35 S 0725932/UTM4010524 & 2 \\
\hline 26 & Kaș2 & 35 S 0716651/UTM 4017123 & 19 \\
\hline
\end{tabular}


alanlarında, tesadüf blokları deneme deseninde üç tekrarlamalı olarak yürütülmüștür. Çiçeklenme bașlangıcında toplanan 26 adi yonca (Medicago sativa L.) genotipi klonla çoğaltılarak, her tekerrürde 30 bitki olacak șekilde $1 \times 1$ sıra arası ve sıra üzeri mesafede deneme kurulmuștur. Klonların dikimi öncesi toprak hazırlığı esnasında dekara 16 kg da-1 triple süper fosfat ve $8 \mathrm{~kg}$ da-1 amonyum sülfat olacak șekilde deneme alanına gübre uygulanmıștır. Bitkiler \%10 çiçeklenme döneminde iken toprak yüzeyinden $5 \mathrm{~cm}$ anız bırakılacak șekilde, birinci yılında 5 biçim, ikinci yılında ise 7 biçim yapılmıștır.

Kullanılan bitkisel materyallere ait koordinat ve rakım değerleri Çizelge 1'de verilmiștir. Denemenin yürütüldüğü alana ait toprak; milli kil bünyeye sahip, tuzsuz, çok yüksek kireçli, kuvvetli alkali, organik madde içeriği düșük, yüksek fosfor, yüksek kalsiyum, çok yüksek magnezyum, orta düzeyde potasyum, yeterli mangan, demir ve bakır ile yetersiz çinkoya sahiptir.

İklimsel olarak deneme alanında, kıșları lık ve yağıșlı, yazları sıcak ve kurak geçen tipik Akdeniz iklimi hüküm sürmektedir. Her iki yılda da (2013-2014) iklim özellikleri bakımından denemenin seyrini değiștirecek herhangi bir olumsuz durum gerçekleșmemiștir (Çizelge 2).
Kalite kriterlerini belirlemek amacıyla yapılan analizde kullanılacak örnekler, $30 \mathrm{~m}^{2}$ alanda bulunan genotiplerin 3 . biçimlerinde (birinci yıl 30 Temmuz, ikinci yıl 9 Mayıs) ve \%10 çiçeklenme devrelerinde alınmıștır.

HP oranları belirlenirken genotiplere ait bitkilerden her tekerrürden $5^{\prime}$ 'er bitkiden örnekler alınmıștır. 48 saat $70^{\circ} \mathrm{C}$ 'de kurutularak, blender ile öğütüldükten sonra 0.5 $\mathrm{g}$ örnek alınarak Kjeldahl metoduna göre azot analizi yapılmıștır (Kacar ve İnal, 2008). Elde edilen oranlar 6.25 katsayısıyla çarpılarak ham protein oranları tespit edilmiștir.

ADF oranları belirlenirken; F57 keselerine $0.5 \mathrm{~g}$ örnek tartııp hot seilor ile kapatımıș, fiber analiz cihazında $60 \mathrm{dk}$ ADF solüsyonuyla (Daha önce standartlaștırımıș $1 \mathrm{~L} 1.00 \mathrm{~N} \mathrm{H}_{2} \mathrm{SO}_{4}$ 'e $20 \mathrm{~g}$ setil trimetilamonyum bromür (CTAB) eklenmiș solüsyon/ANKOM'dan sağlanmıștır) ișlem gördükten sonra $3 \mathrm{kez}$ saf suyla yıkama ișlemi (2 kez sıcak su ve 1 kez soğuk su 5'er dk olmak üzere) yapılmıștır. Preslenen keseler $3 \mathrm{dk}$ asetonda bekletildikten sonra $105^{\circ} \mathrm{C}$ 'de $4-5$ saat kurutulmuș ve tartılarak asit deterjan lif oranı belirlenmiștir (Albayrak ve ark. 2009). NDF oranları belirlenirken; örnekler, NDF solüsyonuyla ( $1 \mathrm{~L}$ distile suya $30 \mathrm{~g}$ Sodium dodecyl sulfate (USP), $18.61 \mathrm{~g}$ Ethylenediaminetetraacetic disodium tuzu

Çizelge 2. Tarla denemelerinin yürütüldüğü 2013-2014 ve uzun yıllara ait bazı iklim verileri (Anonim, 2014)

Table 2. Climate Data (2013-2014- Long Period)

\begin{tabular}{lrrrrrrrrr}
\hline \multirow{3}{*}{ Aylar } & \multicolumn{3}{c}{2013} & \multicolumn{3}{c}{2014} & \multicolumn{3}{c}{ Uzun yıllar } \\
\cline { 2 - 6 } & $\begin{array}{r}\text { Yağıș } \\
(\mathrm{mm})\end{array}$ & $\begin{array}{r}\text { Nispi } \\
\text { nem }(\%)\end{array}$ & $\begin{array}{r}\text { Sıcaklık } \\
\left({ }^{\circ} \mathrm{C}\right)\end{array}$ & $\begin{array}{r}\text { Yağıș } \\
(\mathrm{mm})\end{array}$ & $\begin{array}{r}\text { Nispi nem } \\
(\%)\end{array}$ & $\begin{array}{r}\text { Sıcaklık } \\
\left({ }^{\circ} \mathrm{C}\right)\end{array}$ & $\begin{array}{r}\text { Yağıș } \\
(\mathrm{mm})\end{array}$ & $\begin{array}{r}\text { Nispi } \\
\text { nem }(\%)\end{array}$ & $\begin{array}{r}\text { Sıcaklık } \\
\left({ }^{(} \mathrm{C}\right)\end{array}$ \\
\hline Ocak & 203 & 74.4 & 10.2 & 224 & 68 & 8.65 & 224.9 & 9.8 & 15 \\
Șubat & 59 & 74.9 & 12.1 & 112 & 64.6 & 8.2 & 156.3 & 10.4 & 15.5 \\
Mart & 19 & 69.7 & 13.3 & 66 & 57.5 & 12.15 & 96.2 & 12.7 & 18 \\
Nisan & 34 & 67.1 & 17.7 & 51 & 62.2 & 16.9 & 58.3 & 16.1 & 21.3 \\
Mayıs & 56 & 66 & 22.5 & 64 & 72 & 20.9 & 31.8 & 20.5 & 25.6 \\
Haziran & 0 & 61.6 & 25.4 & 4 & 63.4 & 27 & 7.9 & 25.4 & 30.9 \\
Temmuz & 16 & 57.8 & 28 & 0 & 61.3 & 29.8 & 3 & 28.4 & 34.1 \\
Ağustos & 0 & 57.6 & 28.7 & 0 & 59.6 & 28.65 & 2.4 & 28.2 & 34.2 \\
Eylül & 19 & 58 & 24.7 & 20 & 60.4 & 25.11 & 13.7 & 24.7 & 31.2 \\
Ekim & 89 & 53.4 & 18.1 & 65 & 57.7 & 19.87 & 78.8 & 20 & 26.6 \\
Kasım & 179 & 71.5 & 15.9 & - & - & - & 137.1 & 14.9 & 21.1 \\
Aralık & 53 & 58 & 9.56 & - & - & - & 259.4 & 11.3 & 16.6 \\
Yıllık & 727 & - & - & 606 & - & - & 1069.8 & - & - \\
\hline
\end{tabular}


(dehydrate), 6.81g Sodium borate, $4.56 \mathrm{~g}$ Sodium phosphate dibasic (anhydrous), ve 10.0ml Triethylene glycol eklenerek hazırlanır/ ANKOM'dan sağlanmıștır) $75 \mathrm{dk}$ ișlem gördükten sonra 3 kez saf suyla yıkama-2 sıcak su (1900-2000 mL sıcak suda $4 \mathrm{ml}$ alfa amilaz enzimi kullanılmıș) sonra 1 kez soğuk su (5'er dk) ișlemi yapılmıștır. Preslenen keseler 3 dk \%99.8'lik asetonda bekletildikten sonra $105^{\circ} \mathrm{C}$ 'de 4-5 saat kurutulmuș ve tartılarak nötral deterjan lif oranı belirlenmiștir (Albayrak ve ark. 2009).

Denemeden elde edilen veriler, SAS paket programında varyans analizine tabi tutulmuș (SAS Institute, 1998), olușan farklılıklar Duncan testine göre gruplandırılmıștır (Düzgüneș ve ark. 1987).

\section{Bulgular ve Tartıșma}

Araștırmada incelenmiș olan ham protein oranı, ADF ve NDF içeriklerine ait yıl birleștirmesi yapılarak hazırlanmıș olan varyans analiz sonuçları Çizelge 3'te verilmiștir. Yonca genotipleri arasında ham protein, asit deterjan fiber ve nötr deterjan fiber oranına ilișkin değerlerle yapılan varyans analizi sonucunda her üç özellik açısından genotipler arasında istatistiksel olarak farklılık önemli bulunurken, yıl x genotip interaksiyonları istatistiki olarak önemsiz bulunmuștur.

\section{HP Oranı;}

Ham protein oranı bakımından, genotipler arasında istatistiki olarak \%1 düzeyinde farklılıklar belirlenmiștir. Yonca genotiplerinde ham protein oranları en yüksek \%17.86 - 17.81

Çizelge 3. HP, ADF ve NDF oranlarına (\%) ait varyans analiz sonuçları

Table 3. Analysis of variants of $C P, A D F$ and NDF (\%)

\begin{tabular}{lcccc}
\hline $\begin{array}{l}\text { Varyasyon } \\
\text { kaynakları }\end{array}$ & S.D & HP & ADF & NDF \\
\hline YIl & 1 & 6.180 & $321.75^{* \star}$ & $248.04^{\star *}$ \\
Blok & 4 & 1.58 & $11.18^{*}$ & 2.66 \\
Genotip & 25 & $11.79^{\star \star}$ & $13.40^{\star \star}$ & $14.23^{\star \star}$ \\
YılxGenotip & 25 & 0.04 & 3.50 & 0.850 \\
Hata & 100 & 1.96 & 3.20 & 3.75 \\
\hline $\mathrm{CV} \mathrm{( \% )}$ & 8.86 & 4.87 & 4.10 \\
\hline${ }^{*} 0.05,{ }^{* *} 0.01$ düzeyinde önemlidir. & &
\end{tabular}

- 17.52 ve \%17.36 ile sırasıyla; Finike1, Finike2, Gazipașa1 ve Aksu2 genotipleri olmuștur. En düșük ham protein oranı ise \%12.75 ile Kaș-2 genotipi olmuștur (Çizelge 4).

Farklı araștırmalarda belirlenen yonca ham protein oranları incelendiğinde; Avcı ve ark. (2010) \%16.7-18.2, Töngel ve Ayan (2010) \%20.62-23.76, Turan (2010) \%16.3-16.4, Stanacev ve ark., (2010) \%19.7, Avcı ve ark. (2011) \%16, Monirifar (2011) \%21.31-25.35, Yüksel (2012) \%16.07, Albayrak ve ark. (2014) \%18.69-14.10 olarak bulmușlardır. Elde edilen sonuçlar, Töngel ve Ayan (2010) Stanacev ve ark., (2010) ve Monirifar (2011)'dan düșük bulunurken, diğer araștırma sonuçları ile benzerlik göstermektedir. Ham protein oranları arasındaki farklılığa, araștırmada kullanılan yonca genotiplerinin farklı olmasının yanı sıra, farklı biçim zamanları ve farklı çevre koșullarının da etkin rol oynadığı söylenebilir. Nitekim Vough ve Merten (1971) yaptıkları araștırmada sıcaklık artıșına paralel olarak bitkide yaprak ve protein oranının arttığını, Açıkgöz (2001) yonca otunun kimyasal kompozisyonunun bölgeye, çeșide, toprak yapısına ve iklim șartlarına, biçim devresi ve kurutma yöntemlerine göre değișiklik gösterdiğini ve biçim geciktikçe ham protein oranının azaldığını bildirmiștir. Bu sonuçlar da farklılığa dair tezimizi destekler niteliktedir.

\section{ADF Orani;}

Yonca genotipleri arasında ADF oranı bakımından yıl $x$ genotip interaksiyonu istatistiki olarak önemsiz bulunurken, yıllar ve genotipler arasındaki farklılık istatistiki olarak $\% 1$, bloklar arası ise $\% 5$ düzeyinde önemli bulunmuștur (Çizelge 3). İkinci yıl ADF oranı ortalama \%38.15 ile daha yüksek tespit edilirken, birinci yıl ise \%35.24 olarak tespit edilmiștir. İki yılın ortalama değerlerinde en düșük ADF oranları; \%34.48, \%34.72, \%35.03 ve \%35.05 ile sırasıyla Finike2, Kaș1, Kepez2 ve Kemer1, genotipleri olmuș, en yüksek ADF oranı ise \%39.45 ile Serik2 genotipinde belirlenmiștir (Çizelge 4).

Yoncada farklı bölge ve farklı çeșitlerle yapılan çalıșmalarda tespit edilen ADF oranları sırasılya; Tucak ve ark., (2008) \%30.16-35.91, Katic ve ark., (2009) \%37.4-39.5, Scholtz ve ark., (2009) \%21.3-47.2, Avcı ve ark. (2009) 
Çizelge 4. HP, ADF ve NDF oranlarına ait ortalama değerler (\%)

Table 4. Mean values of (\%) CP, ADF and NDF

\begin{tabular}{|c|c|c|c|c|c|c|c|c|c|}
\hline \multirow{2}{*}{ Lokasyon } & \multicolumn{3}{|c|}{ HP Oranı } & \multicolumn{3}{|c|}{ ADF Oranı } & \multicolumn{3}{|c|}{ NDF Oranı } \\
\hline & 2013 & 2014 & Ortalama & 2013 & 2014 & Ortalama & 2013 & 2014 & Ortalama \\
\hline Gazipașa1 & $17.84 \mathrm{ab}$ & $17.20 \mathrm{ab}$ & $17.52 \mathrm{a}$ & $32.62 \mathrm{hl}$ & $38.45 \mathrm{ad}$ & $35.53 \mathrm{fl}$ & 44.74 be & $46.73 \mathrm{el}$ & $45.73 \mathrm{hk}$ \\
\hline Gazipașa2 & $13.59 \mathrm{hl}$ & $13.38 \mathrm{gf}$ & $13.48 \mathrm{hl}$ & $37.30 \mathrm{ad}$ & $39.27 \mathrm{ac}$ & $38.26 \mathrm{ad}$ & $48.09 a b$ & 49.64 ae & $48.86 \mathrm{ae}$ \\
\hline Alanya1 & 16.59 af & $16.53 \mathrm{a}-\mathrm{d}$ & $16.56 \mathrm{ae}$ & 35.19 al & $39.85 a b$ & 37.52 af & 45.05 be & $46.56 \mathrm{fl}$ & $45.80 \mathrm{hk}$ \\
\hline Alanya2 & $15.43 \mathrm{ch}$ & $15.23 \mathrm{bf}$ & $15.33 \mathrm{cg}$ & $38.16 \mathrm{ab}$ & $40.45 \mathrm{a}$ & $39.30 \mathrm{ab}$ & $47.86 \mathrm{ac}$ & $51.19 \mathrm{a}$ & $49.52 \mathrm{ac}$ \\
\hline Manavgat1 & $15.39 \mathrm{ch}$ & $15.01 \mathrm{bf}$ & $15.23 \mathrm{dg}$ & $37.28 \mathrm{ad}$ & $39.30 \mathrm{ac}$ & $38.29 \mathrm{ad}$ & $46.42 \mathrm{ae}$ & 49.39 af & 47.90 ah \\
\hline Manavgat2 & $15.21 \mathrm{dl}$ & $14.77 \mathrm{cg}$ & $14.99 \mathrm{eh}$ & $35.86 \mathrm{ag}$ & $39.45 a b$ & $37.65 \mathrm{ae}$ & $49.06 \mathrm{a}$ & $51.09 \mathrm{a}$ & $50.07 \mathrm{a}$ \\
\hline Serik1 & $14.38 \mathrm{fl}$ & $13.93 \mathrm{eg}$ & $14.16 \mathrm{fl}$ & $37.28 \mathrm{ad}$ & $39.55 \mathrm{ab}$ & $38.41 \mathrm{ac}$ & $45.73 \mathrm{ae}$ & $48.51 \mathrm{ah}$ & 47.12 ej \\
\hline Serik2 & $15.51 \mathrm{ch}$ & $15.41 \mathrm{af}$ & $15.46 \mathrm{cg}$ & $38.82 \mathrm{a}$ & $40.08 \mathrm{a}$ & $39.45 \mathrm{a}$ & 46.29 ae & $49.81 \mathrm{ac}$ & $48.05 \mathrm{ag}$ \\
\hline Aksu1 & 16.79 ae & $16.22 \mathrm{ad}$ & $16.51 \mathrm{ae}$ & $32.82 \mathrm{gl}$ & $38.37 \mathrm{ae}$ & $35.59 \mathrm{fl}$ & 44.75 be & 47.97 bl & $46.36 \mathrm{fk}$ \\
\hline Aksu2 & $17.64 \mathrm{ac}$ & $17.09 a b$ & $17.36 \mathrm{a}$ & $34.32 \mathrm{cl}$ & $36.01 \mathrm{df}$ & 35.17 hı & $44.06 \mathrm{de}$ & $46.32 \mathrm{hı}$ & $45.19 \mathrm{jk}$ \\
\hline Kepez1 & 16.71 af & $16.35 \mathrm{ad}$ & $16.53 \mathrm{ae}$ & $34.55 \mathrm{cl}$ & $36.00 \mathrm{df}$ & 35.27 hı & $46.37 \mathrm{ae}$ & 48.90 ah & $47.63 \mathrm{bh}$ \\
\hline Kepez2 & $15.83 \mathrm{ah}$ & 15.40 af & $15.62 \mathrm{bg}$ & 32.26 I & 37.87 af & 35.05। & $46.75 \mathrm{ad}$ & $50.18 \mathrm{ab}$ & 48.46 af \\
\hline Döșemealtı1 & 16 & 1 & 16 & $\mathrm{cc}$ & 38. & 38 & 44 & $\mathrm{Cl}$ & 45 \\
\hline Döșemealtı2 & $14.76 \mathrm{el}$ & $14.55 \mathrm{dg}$ & 14.66 fh & $37.19 \mathrm{ad}$ & $38.88 \mathrm{ac}$ & $38.03 \mathrm{ad}$ & $48.03 a b$ & $51.18 \mathrm{a}$ & $49.60 a b$ \\
\hline Konyaaltı1 & $17.05 \mathrm{ae}$ & $16.80 \mathrm{ac}$ & $16.93 \mathrm{ac}$ & $36.62 \mathrm{ae}$ & $38.12 \mathrm{ae}$ & $37.37 \mathrm{bg}$ & 46.06 ae & 48.44 ah & $47.25 \mathrm{dj}$ \\
\hline Konyaaltı2 & $16.15 \mathrm{ag}$ & $15.33 \mathrm{bf}$ & 15.74 bf & $34.17 \mathrm{~d} \mathrm{l}$ & 38.34 ae & $36.25 \mathrm{~d} ı$ & 47. & 48.39 ah & $47.71 \mathrm{bh}$ \\
\hline Kemer1 & $16.86 \mathrm{ae}$ & $16.49 \mathrm{ad}$ & $16.67 \mathrm{ad}$ & $33.30 \mathrm{fl}$ & $36.76 \mathrm{cf}$ & 35.031 & 45.17 be & $46.78 \mathrm{dı}$ & $45.97 \mathrm{gk}$ \\
\hline Kemer2 & 13.68 hı & $13.28 \mathrm{gf}$ & $13.48 \mathrm{hl}$ & $37.26 \mathrm{ad}$ & $39.30 \mathrm{ac}$ & $38.28 \mathrm{ad}$ & 46.92 & 49.7 & 48.32 af \\
\hline Kumluca1 & $14.16 \mathrm{gh}$ & $13.94 \mathrm{eg}$ & $14.05 \mathrm{gl}$ & 36.21 af & $38.17 \mathrm{ae}$ & $37.20 \mathrm{ch}$ & $48.04 a b$ & $50.81 \mathrm{ab}$ & $49.42 \mathrm{ad}$ \\
\hline Kumluca2 & 16.69 af & $16.14 \mathrm{ae}$ & $16.42 \mathrm{ae}$ & 33.52 el & $38.02 \mathrm{ae}$ & 35.77 el & $45.74 \mathrm{ae}$ & $49.32 \mathrm{ag}$ & $47.53 \mathrm{bl}$ \\
\hline Finike1 & $18.17 \mathrm{a}$ & $17.55 \mathrm{a}$ & $17.86 \mathrm{a}$ & $8 \mathrm{cl}$ & 37 & el & e & $\mathrm{Cl}$ & jk \\
\hline Finike2 & $18.04 \mathrm{a}$ & $17.58 \mathrm{a}$ & $17.81 \mathrm{a}$ & $33.70 \mathrm{el}$ & $35.27 f$ & 34.48 I & 45.79 ae & $47.11 \mathrm{cl}$ & $46.45 \mathrm{fk}$ \\
\hline Demre1 & $16.85 \mathrm{ae}$ & $16.46 \mathrm{ad}$ & $16.65 \mathrm{ad}$ & 35.26 al & 37.25 bf & $36.25 \mathrm{dl}$ & $44.34 \mathrm{de}$ & $46.40 \mathrm{gl}$ & $45.37 \mathrm{lk}$ \\
\hline Demre2 & $16.43 \mathrm{ag}$ & 16.12 ae & $16.28 \mathrm{ae}$ & $32.65 \mathrm{hl}$ & $38.11 \mathrm{ae}$ & $35.38 \mathrm{gl}$ & 45.30 be & $48.32 \mathrm{ah}$ & 46.81 ej \\
\hline Kaș1 & $17.44 \mathrm{ad}$ & $16.90 \mathrm{ac}$ & $17.17 \mathrm{ab}$ & 33.67 el & 35.77 ef & 34.72 I & $43.70 \mathrm{de}$ & 45.33 I & $44.51 \mathrm{k}$ \\
\hline Kaș2 & 12.92 I & $12.58 \mathrm{~g}$ & 12.75 I & 35.67 ah & 37.32 bf & $36.49 \mathrm{cl}$ & $46.02 \mathrm{ae}$ & 48.65 ah & $47.33 \mathrm{cj}$ \\
\hline Ortalama & 16.03 & 15.63 & 15.83 & $35.24 \mathrm{~B}$ & $38.15 \mathrm{~A}$ & 36.72 & $45.97 \mathrm{~B}$ & $48.49 \mathrm{~A}$ & 47.23 \\
\hline
\end{tabular}

\%41, Bașbağ ve ark. (2009) \%20.3-35.2, Avcı ve ark. (2010) \%40.3-50.4, Avcl ve ark. (2011) \%35, Monirifar (2011) \%38.83-44.70, Yılmaz (2011) \%30.26-33.44, Albayrak ve ark. (2014) \%30.8 arasında bulmușlardır.

Söz konusu araștırmada ADF oranları; Monirifar (2011), Avcı ve ark. (2010) ve Avcı ve ark. (2009)'den düșük bulunurken, diğer araștırma sonuçlarılyla paralellik arz etmektedir. Farklılığın sebebi olarak Yavuz, (2005 b)'un da belirttiği üzere, bitkinin çeșidi, analiz için alınan örneğin aksamı, bitkinin vejetasyon süresi, hasat zamanı, fiziksel ve kimyasal ișlemlerinin yapılıp yapılmaması gibi hususlar olduğu söylenebilir.

\section{NDF Orani;}

Araștırmada yıllar ve genotipler arasındaki farklılık istatistiki olarak \%1 düzeyinde önemli bulunmuș olup (Çizelge 3), ADF oranında olduğu gibi ikinci yıl ortalama NDF oranı $\% 48.49$, ikinci yıl ise ortalama \%45.97 olarak tespit edilmiştir. İki yılın ortalama değerleri sonucunda en düșük NDF oranı \%44.51 ile Kaș1 genotipinde belirlenirken, en yüksek 
NDF oranları \%50.07 ortalama ile Manavgat2 genotipinde bulunmuștur (Çizelge 4). Yonca otunda farklı ekolojik bölgeler ve çeșitlere bağlı olarak ADF oranları; Katic ve ark., (2009), \%45.4-48.7, Avcl ve ark. (2009) 48.9, Scholtz ve ark., (2009) \%28.9-65.9, Avcl ve ark. (2010) \%47.5-50.4, Avcl ve ark. (2011), \%40, Monirifar (2011) \%47.03-57.43, YIImaz (2011) $\% 42.27-44.98$, Albayrak ve ark. (2014) \%41.8 olarak bulmușlardır. Bitkinin farklı kısımlarında, farklı biçim zamanlarında, farklı uygulamalar ve farklı gelișme evrelerinde așağıdaki NDF oranları tespit edilmiștir. Mustafa ve ark. (2001) NDF oranlarını; soldurulmuș yoncada \%43, kurutulmușta \%55.6 ve sıkıștııılmıșta \%50.8 elde etmișlerdir. Niwinska ve ark., (2005) birinci biçimde \%46.3, ikinci biçimde $\% 50.1$, üçüncü biçimde $\% 44.4$ olarak tespit etmișlerdir. Markovic ve ark., (2008) bitkinin yapraklarında \%44.9, sapında \%56.5 NDF oranı kaydetmișlerdir. Pop ve ark., (2008) tomurcuklanmada \% 42.0, erken çiçeklenme $\% 45.0$ ve tam çiçeklenme devrelerinde $\% 48.3$ NDF oranı tespit etmișlerdir. Araștırmada elde edilen sonuçlar Avcı ve ark. (2011) ve Albayrak ve ark. (2014)'nın elde ettiği sonuçlardan yüksek bulunurken, diğer çalıșmalarla benzerlik göstermektedir.

\section{Sonuç}

Antalya doğal florasından toplanan 26 farklı yerli yonca genotipinin bazı kalite özelliklerinin belirlenerek, buradan elde edilecek veriler doğrultusunda ileri kademe ıslah çalıșmalarına materyal temin edilmesi amacıyla gerçekleștirilen bu deneme sonucunda; yonca genotiplerinde en yüksek ham protein oranı \%17.52-16.27 aralığı ile Gazipașa1, Alanya1, Aksu1, Aksu2, Kepez1, Döșemealtı1, Konyaaltı1, Kemer1, Kumluca2, Finike1, Finike2, Demre1, Demre2 ve Kaș1 olmak üzere toplam 14 genotipte belirlenirken, en düșük ham protein oranı \%12.75 ile Kaș2 genotipinde tespit edilmiștir. ADF oranları $\% 35.03-39.45$, NDF oranları ise \%44.5150.07 arasında değișim göstermiștir. Bu sonuçlara göre; Gazipașa1 Alanya1 Aksu2 Kepez1 Döșemealtı1 Konyaaltı1 Kemer1 Finike2 Demre1 ve Kaș1 genotipleri kalite özellikleri açısından üstün bulunarak, ileri ıslah kademesine aktarılmıștır.

\section{Teșekkür}

Bu çalıșma Süleyman Demirel Üniversitesi, Fen Bilimleri Enstitüsü'nde yürütülen Doktora çalıșmasının bir bölümünü içermektedir. SDÜ-BAP-3190-D1-12 numaralı projeyi maddi olarak destekleyen Süleyman Demirel Üniversitesi Bilimsel Araștırma Projeleri Yönetim Birimi Bașkanlığı'na teșekkür ederim.

\section{Kaynaklar}

Açıkgöz, E. (2001). Yem Bitkileri, VIPAS Yayın No 58, 584s. Bursa.

Albayrak, S., Türk, M., \& Yüksel, O. (2009). Effects of phosphorus fertilization and harvesting stages on forage yield and quality of Woolypod Vetch. Turkish Journal of Field Crops, 14(1), 30-40.

Albayrak, S., Türk, M., Sevimay, C.S., Kazaz, S., \& Tong, M. (2014). Göller Yöresinde adi yonca (Medicago sativa L.) populasyonlarının toplanması ve karakterizasyon çalıșmaları, TUBITAK Proje No 1100257 Sonuç raporu. 74s.

Avcı, M., Çınar, S., Kızıl, S., Aktaș, A., Yücel, C., Hatipoğlu, R., ... Yücel, H., Kılıçalp, N., İnal, I., Gültekin, R. (2009). Çukurova taban koșullarında farklı yonca çeșitlerinin ot verimleri ve ot kalitesi üzerine bir araștırma. Türkiye VIII. Tarla Bitkileri Kongresi, 19-22 Ekim, Hatay.

Avcı, M., Çınar, S., Yücel, C., \& İnal, İ. (2010). Evaluation of some selected alfalfa (Medicago sativa L.) lines for herbage yield and forage quality. Çukurova Agricultural Research Institute, 8(3\&4), 545-549.

Avcı, M., Çınar, S., Yücel, C., Kızıl Aydemir, S., \& Hatipoğlu, R. (2011). Farklı yonca genotiplerinin dormansi oranları ile verim ve verim unsurları arasındaki ilișkiler. Türkiye IX. Tarla Bitkileri Kongresi, 12-15 Eylül, Bursa,

Bașbağ, M., Demirci, R., \& Avcl, M. (2009). Determination of some agronomical and quality properties of wild alfalfa (Medicago sativa I.) clones in Turkey. Journal of Food Agriculture and Environment, 7(2), 357-359.

Budak, F. \& Budak, F. 2014. Yem Bitkilerinde kalite ve yem bitkileri kalitesini etkileyen faktörler. Türk Bilimsel Derlemeler Dergisi (7)1:01-06.

Düzgüneș O., Kesici, T., \& F. Gürbüz. (1987). Araștırma ve Deneme Metodları (İstatistik Metodları-II). Ankara Üniv. Ziraat Fak. Yay.1021, Ders Kit. 295.

Gençkan, M.S., (1983). Yem Bitkileri Tarımı. Ege Üniv. Ziraat Fak. Yay. No 464 519. s: 5-6 İzmir.

Güney, M., Bingöl, N., \& Aksu,T. (2016). Kaba yem kalitesinin sınıflandırımasında kullanılan göreceli yem değeri (GYD) ve göreceli kaba yem kalite indeksi (GKKI). Atatürk Üniversitesi Vet. Bil. Derg.11(2): 254-258

Kacar, B., \& İnal, A. (2008). Bitki Analizleri. Nobel yayınları. No: $1241,892 s$, Ankara. 
Karagül T.E. (2017) Türkiye Yemeklik Tane Baklagil Genetik Kaynakları. Anadolu, J. of AARI 27(1), 56-70.

Katić, S., Milić, D., Karagić, D., Vasiljević, S., Glamočić, D., \& Jajić, I. (2009). Variation of protein, cellulose and mineral contents of lucerne as influenced by cultivar and cut. Biotechnology in Animal Husbandry, http://istocar.bg.ac.rs/ radovi8/2/73.engl.S.Katicsr.

Kutlu, H.R. (2008). Yem Değerlendirme ve Analiz Yöntemleri. Çukurova Üniversitesi Ziraat Fakültesi Zootekni Bölümü, Ders Notu, Adana.

Manga, Ü., Acar, Z., Ayan, İ., 1995. Baklagil Yem Bitkileri. Ondokuz Mayıs Üniversitesi Ziraat Fakültesi Ders Notu No 7.

Marković, J., Radović, J., Lugıć, Z., \& Sokolović, D., (2008). Nutritive value in leaves and stems of lucerne with advanced maturity and a comparison of methods for determination of lignin content. Proceedings of the 22nd General Meeting of the European Grassland Federation, 9-12 June, Sweeden, 480 -482.

Monirifar, H., (2011). Path analysis of yield and quality traits in alfalfa. Not Bot Horti Agrobo, 39(2):190-195

Mustafa, A. F., Christensen, D.A., \& McKinnon, J.J., (2001). Chemical composition and ruminal degradability of lucerne (Medicago sativa) product. Wiley Online Library, http://www3. interscience.wiley com /cgi-bin/fulltext.

Niwińska, B., Strzetelskı, J.A., Kowalczyk, J., Borowiec, F., \& Domańskı, F., (2005). The effect of phenological stage and season on nutritive value, chemical composition and nutrient digestibility of lucerne (Medicago sativa L.) green forage in the alimentary tract of cattle. Czech Journal of Animal Sciencehttp://www. cazv.cz /attachments/CJAS 50, 511-518.

Pop, I.M., Radu-Rasu, C.G., Simeanu, D., Albu, A., \& Popa, V., (2008). Characterization of the nutritional value of alfalfa harvested at different stages of vegatation using cell walls content based. University of Agricultural Sciences and Veterinary Medicine, 53, 190-194.

SAS Institute, (1998). INC SAS/STAT users' guide release 7.0, Cary, NC, USA.

Scholtz, G.D.J., Merwe, H. J., \& Tylutki, T. P. (2009). The nutritive value of South African medicago sativa L. hay. South African Society for Animal Science, http://www.sasas.co.za/sites/sasas. co.za.
Stanacev, V., Dukic, D., Kovcin, S., Drinic, M., Puvaca, N., \& Stanacev, V., (2010). Nutritive value of the genetically divergent genotypes of lucerne (Medicago sativa L.). Academıc Journals, http://www.academicjournals.org/ ajar/PDF/pdf 202010/4 20 Jun / Stanacev.

Tekce, E., \& Gül, M. (2014). Ruminant beslemede NDF ve ADF'nin önemi. Atatürk Üniversitesi Vet. Bil. Derg. 9(1): 63-73.

Töngel, M.Ö., \& Ayan, İ. (2010). Nutritional contents and yields performances of lucerne (Medicago sativa I.) cultivarsi southern black sea shores. Journal of Animal and Veterinary Advances, 15, 2067-2073.

Tucak, M., Popovic, S., Bolaric, S., \& Kozumplik, V. (2008). Agronomic evaluation of alfalfa genotypes under ecological comditions of Eastern Croatia. VII. Alps-Adria Scientific Workshop, Cereal Research Communications, 36, 651- 654 .

Turan, N. (2010). Bazı yonca (Medicago sativa L.) çeşitlerinin farklı ekim zamanlarında verim ve verim unsurlarının belirlenmesi üzerinde bir araştırma. Yüzüncü Yıl Üniversitesi, Fen Bilimleri Enstitüsü Tarla Bitkileri Anabilim Dalı, Doktora Tezi, 113s, Van.

Vough, L.R., \& Merten, G.C., (1971). Influence of soil moisture and ambient temperature on yield and quality of alfalfa forage. Agronomy Journal. 63.

Yavuz, M. (2005 a). Bazı Ruminant Yemlerinin Nispi Yem Değeri ve İn vitro Sindirim Değerlerinin Belirlenmesi. GOÜ. Ziraat Fakültesi, 22 (1), 97101.

Yavuz M., (2005 b. Deterjan lif sistemi. G. O. Ü. Ziraat Fak. Derg., 22, 93-96.

Yılmaz, M., (2011). Isparta ekolojik koșullarında bazı yonca (Medicago sativa L.) çeşitlerinin ot verim ve kalitelerinin belirlenmesi. Süleyman Demirel Üniversitesi, Fen Bil. Enstitüsü Tarla Bitkileri Anabilim Dalı, Yüksek Lisans Tezi, $35 \mathrm{~s}$, Isparta.

Yüksel, O., (2012). Suni çayır tesisinde yonca (Medicago sativa L.) ile karıșıma girebilecek buğdaygil yem bitkilerinin ve en uygun karıșım oranlarının belirlenmesi. Süleyman Demirel Üniversitesi Fen Bilimleri Enstitüsü Tarla Bitkileri Anabilim Dalı, Doktora Tezi, 129s, Isparta. 